\title{
Plea for female academics in Germany
}

[MUNICH] German universities should introduce recruitment and employment policies designed to increase the number of female academics, and should be rewarded financially for their success in doing so, says a report by the Wissenschaftsrat, Germany's influential science council.

The report was drawn up by a panel chaired by Dagmar Schipanski, a former president of the Wissenschaftsrat. One suggestion is that German universities should move towards the Anglo-Saxon system of postdoctoral fellowships, which is more attuned to the family demands on women.

The German academic community is one of the most male-dominated in the industrial world. Twice as many men as women complete $\mathrm{PhDs}$ - in physics the ratio is as high as 13 to one - and only 4.5 per cent of those in top academic positions are women.

In its report, the Wissenschaftsrat says that Germany is well placed to influence these ratios in the near future, as many faculty members who were hired during the university expansion in the 1960s and 1970s are due to retire in the next few years. But it says that a major restructuring of the academic system is needed to achieve this goal.

For example, German women who wish to raise a family are often discouraged from choosing an academic career by the length of time needed to gain the qualifications required for a university post. These include not just a $\mathrm{PhD}$, but also Habilitation, an advanced qualification designed to prove research and teaching skills (see chart). Habilitation candidates are attached for many years to a particular professor, and the average age of qualification is around 40 .

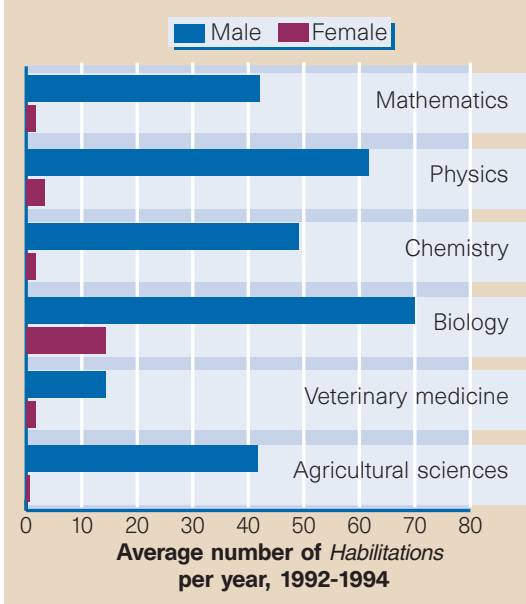

The Wissenschaftsrat's report, entitled Recommendations on Equality of Opportunities for Women in Science and Research, supports a many-pronged approach. It says that universities should take steps to encourage more women to complete PhDs, for example by limiting $\mathrm{PhD}$ duration to three years. It also suggests that universities should ensure that the proportion of women in academic posts - including departmental chairs - is at least as high as the proportion gaining academic qualifications in the same subject.

Rather than enforcing quotas, the Wissenschaftsrat suggests rewarding universities when targets for employing women are met. It suggests that success in promoting women should be a criterion in allocating funds to universities, an idea recently put into practice in the west German state of Hessen.

The report warns against relying on special programmes designed to support female

\section{Authors slow to retract 'fraudulent' papers}

[MUNICH] One year after Germany's biggest fraud scandal became public (see Nature $387,442 ; 1997)$, only two of the 47 scientific papers tainted have been retracted, says the German daily Süddeutsche Zeitung.

According to the newspaper, some co-authors are reluctant to allow retraction out of fear that their careers may be damaged if their names become associated with the fraud. Some young co-authors are said to have threatened to sue the committees investigating the fraud, rather than supporting them by retracting papers.

The Sïddeutsche Zeitung asked the 19 journals that published most of the papers believed by investigating committees to be fraudulent how they had handled the case. The two papers that have been retracted were in the Proceedings of the National Academy of Sciences and in EMBO Journal. According to the newspaper's survey, many of the other journals, including the Journal of Biological Chemistry, the Journal of Immunology and FEBS Letters, claimed that they were completely unaware of the affair.

In seven cases Friedhelm Herrmann, professor of medicine at the University of Ulm - one of the two researchers accused of the fraud, and corresponding author of most of the publications - refused the requests of journal editors to retract papers.

Herrmann says he was unaware that fabrication of data was taking place in his laboratory. Much of the contested work took place in the laboratory headed by Herrmann at the Max Delbrück Centre for Molecular Medicine in Berlin in the early 1990s.

Scientific journals have different policies on the retraction of papers. Some require only the consent of the corresponding author, while others require the agreement of every co-author.
PhD students and Habilitation candidates without a new hiring policy being in place.

The report issues a somewhat circumspect attack on the system of Habilitation. It says that, if a system of postdoctoral fellowships were introduced, research and teaching experience gained in such positions should be accepted as an alternative to Habilitation as proof of competence. Habilitation is often criticized as unnecessary and restricting (see Nature 384, 305; 1996), but is staunchly defended by academic conservatives, who fear the loss of local power for professors.

As the long-drawn-out training means that academics may first apply for permanent posts only around the age of 40 , the report recommends that universities should abandon their system of Hausberufsverbot, whereby an academic position may not be given to a candidate from the same university. Intended to encourage cross-fertilization among universities, this often works against women with young families who are unable to move cities at that stage in their lives.

Experience at other universities should be gained at an earlier stage, says the report. Universities should advertise PhD and postdoctoral positions nationally to encourage mobility among the young. The report points out that this would also increase the quality of competition for such posts.

The report makes the oft-repeated call for more flexible child-care facilities in universities, and for men to accept their share of family responsibilities.

Hans-Gerhard Husung, a spokesman for the Wissenschaftsrat, says that the shortterm and mid-term recommendations form a package that could make a serious difference to an urgent problem.

Brigitte Mühlenbruch, spokeswoman of the German Conference for Quality for Women in Universities, agrees. If all the recommendations are approved, she says, "they will make a big difference to women's employment prospects".

Dagmar Schipanski says she regrets the fall in opportunities for female academics in east Germany since reunification. A much higher number of female than male academics lost their jobs as a result of reunification, and the generous child-care facilities at universities in the east were heavily cut back.

Women were present at all levels of academic life in a higher proportion in the old East Germany than in the west. But Schipanski points out that, despite adequate child-care facilities, the proportion of women at higher levels of the career pyramid still decreased in a manner similar to that in the west.

The Wissenschaftsrat's recommendations do not have legal authority, and it is up to universities to decide if and how far they are adopted.

Alison Abbott 